\title{
What lies beneath ... Late Glacial human occupation of the submerged North Sea landscape
}

\author{
Luc Amkreutz $^{1}$, Alexander Verpoorte ${ }^{2, *}$, Andrea Waters-Rist ${ }^{2}$, \\ Marcel Niekus ${ }^{3}$, Vivian van Heekeren ${ }^{2}$, Alie van der Merwe ${ }^{4}$, Hans van \\ der Plicht ${ }^{2,5}$, Jan Glimmerveen ${ }^{2}$, Dick Stapert ${ }^{6} \&$ Lykke Johansen ${ }^{6}$
}

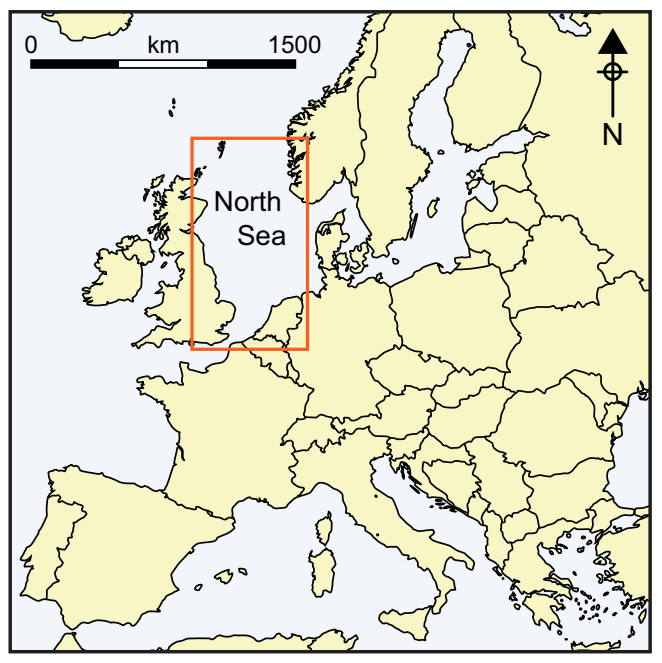

Archaeological evidence from the submerged North Sea landscape has established the rich diversity of Pleistocene and Early Holocene ecosystems and their importance to huntergatherer subsistence strategies. Comparatively little of this evidence, however, dates to the Late Glacial, the period when Northern Europe was repopulated by colonising foragers. A human parietal bone and a decorated bovid metatarsus recently recovered from the floor of the North Sea have been dated to this crucial transitional period. They are set against the background of significant climatic and environmental changes and a major technological and sociocultural transformation. These discoveries also reaffirm the importance of continental shelves as archaeological archives.

Keywords: North Sea, Late Glacial, Allerød, Palaeolithic, continental shelf, hunter-gatherer

\section{Introduction}

Continental shelves are increasingly recognised as important archives of the human past (Benjamin et al. 2011; Evans et al. 2013; Flemming et al. 2014). The sea floor is not just a

1 National Museum of Antiquities, Rapenburg 28, 2311 EW Leiden, the Netherlands

2 Faculty of Archaeology, Leiden University, Einsteinweg 2, 2333 CC Leiden, the Netherlands

3 Stichting STONE/Foundation for Stone Age Research in the Netherlands, clo Lopendediep 28, $9712 \mathrm{NW}$ Groningen, the Netherlands

4 Department of Anatomy, Embryology and Physiology, Academic Medical Center, Meibergdreef 9, 1105 AZ Amsterdam, the Netherlands

5 Centre for Isotope Research, Groningen University, Nijenborgh 4, 9747 AG Groningen, the Netherlands

6 Independent researcher, Ossewei 6, 9751 SC Haren, the Netherlands

*Author for correspondence (Email: a.verpoorte@arch.leidenuniv.nl) 
treasure chest for the history of seafaring; it also preserves a record of the vast periods of time when the continental shelves were dry land. Sea levels during the past million years have rarely been as high as they are today; and for hundreds of thousands of years, the continents were substantially larger (Flemming et al. 2014). Recent finds of hominin fossils as far apart as the North Sea and Taiwan testify to the potential of the shelf record (Hublin et al. 2009; Chang et al. 2014).

The North Sea is probably one of the best-known submerged landscapes in the world (Peeters \& Cohen 2014; Bicket \& Tizzard 2015), covering some $750000 \mathrm{~km}^{2}$. The rich faunal record, mainly brought to the surface by sea-floor fishing, documents the diverse Pleistocene and Early Holocene ecosystems (van Kolfschoten \& Laban 1995; Mol et al. 2006, 2008; Bynoe et al. 2016). These were exploited by early hominins from perhaps one million years ago (Parfitt $e t$ al. 2005, 2010). Neanderthal presence is evidenced by the discovery of a frontal bone and Middle Palaeolithic artefacts, such as bifaces and Levallois cores and flakes (Hublin et al. 2009; Peeters et al. 2009; Tizzard et al. 2014). Most evidence dates to the Early Holocene, including human bones, antler adzes and axes, bone and antler points, and other tools (Louwe Kooijmans 1970; van der Plicht et al. 2016).

Archaeological evidence from the end of the last Ice Age, a key period in the repopulation of Northern Europe after the Last Glacial Maximum, has remained thus far almost invisible in the North Sea (Peeters \& Momber 2014). The only artefact published is the well-known, uniserially barbed antler point, dredged up from the Leman and Ower Bank in 1931 and dated to $11740 \pm 150 \mathrm{BP}$ (OxA-1950, in Housley 1991). A Gulo gulo (wolverine) mandible,

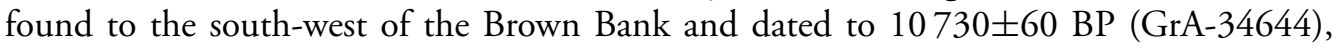
represents one of the few Late Glacial sea-floor faunal remains (Mol et al. 2008). Here we report two finds from the Late Glacial Allerød phase of the Pleistocene-Holocene transition (Figure 1), which represent fragments of submerged biological and cultural heritage from our hunter-gatherer past: a human skull fragment and a decorated bovid bone.

\section{Environmental and archaeological setting}

The end of the last Ice Age is characterised by dramatic climatic fluctuations (Hoek 2008). After an initial rapid rise in temperature at the beginning of Greenland Interstadial 1e (Bølling, 14600-13900 cal BP), temperatures gradually dropped during Greenland Interstadial 1c-a (Allerød, 13900-12800 cal BP). The cooling trend culminated in the cold spike of Greenland Stadial 1 (Younger Dryas, 12 800-11700 cal BP), after which temperatures rose quickly during the Early Holocene. The open grass steppe of Northern Europe was gradually replaced by an open birch and pine forest. Steppe fauna was replaced by species adapted to warmer temperatures and more forested environments with lakes and marshes. Global sea levels rose at an average rate of $12 \mathrm{~m}$ per thousand years during the Late Glacial (Lambeck et al. 2014).

During the Allerød, sea levels were $60-80 \mathrm{~m}$ below the modern level (Lambeck et al. 2002). Most of the North Sea was still dry land, with only the northern part of the North Sea being submerged, due to meltwater from the Scandinavian ice sheet draining through the Norwegian Channel into the northern North Sea (Boulton et al. 2001). A birch and pine forest probably dominated the higher elevations. Open herbaceous vegetation 


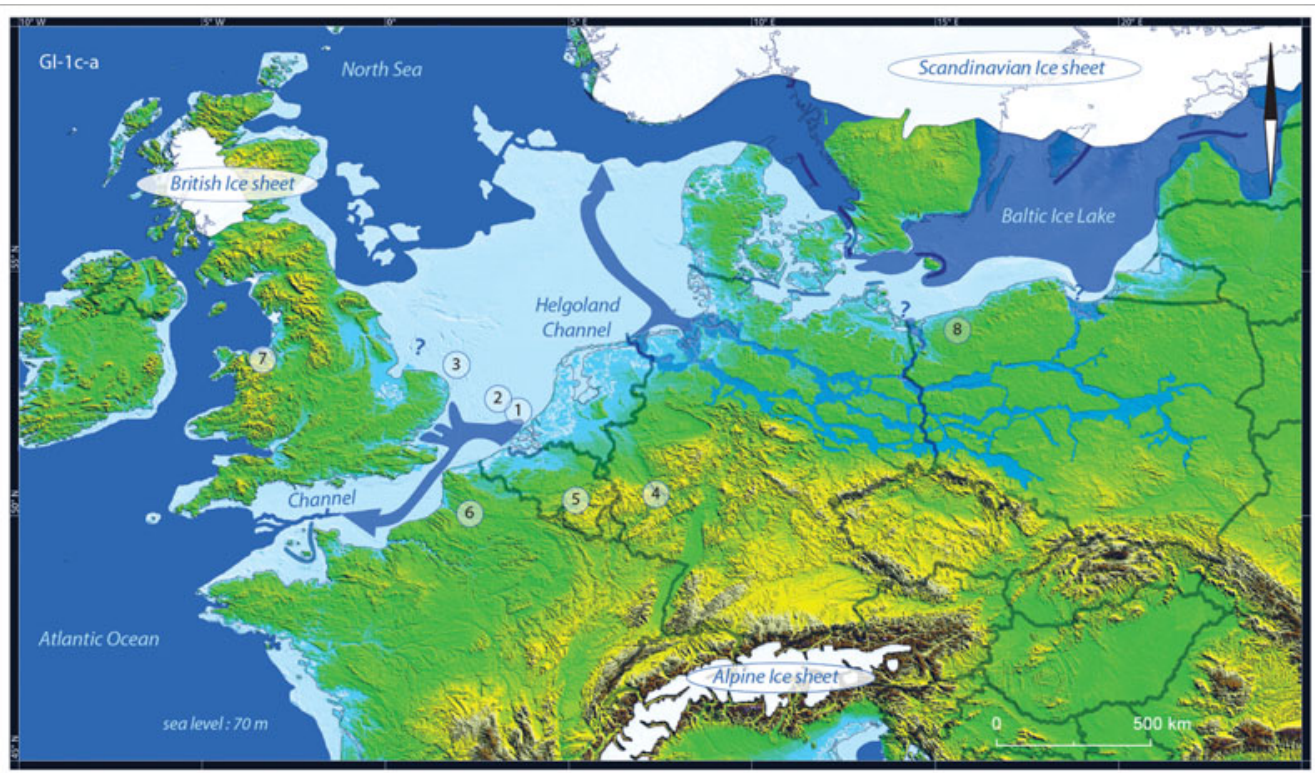

Figure 1. North Sea with the location of the finds; coastline during Greenland Interstadial 1c-a (map compiled by Grimm (2016), after Björck 1995; Boulton et al. 2001; Lundqvist \& Wohlfarth 2001; Weaver et al. 2003; Clark et al. 2004; and Ivy-Ochs et al. 2006). Find locations: 1) Eurogeul; 2) Brown Bank; 3) Leman and Ower Banks; 4) Bonn-Oberkassel and Irlich; 5) Waulsort; 6) Conty; 7) Kendrick's Cave; 8) Rusinowo.

characterised the valley floors (Hoek 2000). Red deer (Cervus elaphus) and European elk (Alces alces) were typical herbivore species (Baales et al. 2002; Aaris-Sørensen 2009). During the cold spike of the Younger Dryas, the vegetation opened up again and aeolian activity increased (Hoek 1997).

At the end of the last Ice Age, human populations recolonised the northern regions of Europe, reaching as far north as southern Scandinavia (Housley et al. 1997; Wygal \& Heidenreich 2014). Ancient mitochondrial DNA indicates that a major population turnover took place in Europe during the Late Glacial (Posth et al. 2017). Important changes in, for example, mobility patterns, settlement structure, subsistence economy, technology and social organisation took place in this period. These were signalled by the transition from the Late Magdalenian tradition (sensu lato including Creswellian and Hamburgian) to the Federmesser-Gruppen or Arch-Backed Point groups, followed by traditions such as Ahrensburgian, Brommian, Laborian and Swiderian during the Younger Dryas. One of the most striking phenomena is the disappearance of naturalistic art (exemplified by Palaeolithic cave art) and the elaboration of geometric art that is more characteristic of the Mesolithic. The two finds described below contribute to our understanding of subsistence and art during the Late Glacial of the southern North Sea.

\section{The finds from the Late Glacial Allerød phase}

Both finds will be discussed in more detail in the following sections. Additional information on the finds as well as figures can be found in the online supplementary material (OSM).

(C) Antiquity Publications Ltd, 2018 


\section{The human parietal bone}

In June 2013, the fishing vessel Scheveningen 18 retrieved a human parietal bone (Figure 2) from the sea floor just south of the Eurogeul, a channel dug in the North Sea, situated to the west of the Port of Rotterdam. It was probably eroded from local Late Glacial sediments, or from the Holocene lag deposit that contains reworked Late Glacial sediments (Hijma et al. 2012). The bone is dated to $11050 \pm 50 \mathrm{BP}$ (GrA-58271) (Table 1).

The human left parietal is well preserved (approximately 70 per cent complete), displaying weathering stage ' 1 ' to ' 2 ', with some cracking and only slight cortical flaking evident (Buikstra \& Ubelaker 1994). Traces of small bryozoan colonies (caused by immersion in seawater) are visible. Parietal eminence thickness and cranial suture closure stage suggest that the individual was probably a young- to middle-aged adult (2245 years old). Slight parietal bossing is present and the superior and inferior temporal lines are not visible. These features are more consistent with a female morphology, although insufficiently diagnostic for sex estimation.

The bone displays no osseous anatomical anomalies or pathological lesions. There are, however, very fine 'pin-head' or shallow pits visible near the sagittal suture. A CT scan reveals no marked expansion of the diploic space or change in the organisation of the trabeculae in the area with pitting. The pitting could be indicative of a porotic hyperostotic episode experienced during subadulthood ( $<18$ years), caused by anaemia (see full discussion in the OSM). Other possible causes of cranial vault pitting such as scurvy, rickets and scalp inflammation as a result of trauma or infection cannot, however, be excluded (Stuart-Macadam 1992; Ortner 2003; Mcllvaine 2013). The lesion is quite well healed, suggesting that, whatever the cause, the individual survived the pathological insult.

\section{The decorated bone}

The decorated bovid bone (Figure 3) was discovered by sea-floor fishing in January 2005 south-west of the Brown Bank in the southern North Sea Basin. The complex sedimentary sequence from the wider area consists of marine, brackish-marine, deltaic and fluviatile Pleistocene sediments, overlain by Holocene marine deposits and the Basal Peat Bed (van Kolfschoten \& Laban 1995). The stratigraphic provenance of the bone is unknown, but it dates to $11560 \pm 50 \mathrm{BP}$ (GrA-28364) (Table 1).

The bone is a large, anterior proximal part of the right metatarsus of a bovid. The presence of a medial tubercle on the facet of the second to third tarsal is more consistent with Bison sp., but is not diagnostic (Gee 1993: 85-86). Approximately 50 per cent of the length and less than half of the circumference have been preserved. The bone surface is relatively well preserved with several long cracks along the length of the bone as well as cortical flaking along the cracks and on the ridges of the proximal part (weathering stage 2 , following Behrensmeyer 1978). Breakage (most probably post-depositional) occurred on several occasions following decoration of the bone. It is not clear if this represents a fragment of a bone tool (e.g. adze).

The decoration of the bone consists of five longitudinal rows of zigzags positioned on flat facets prepared by scraping the bone surface with a flint implement. The central anterior 

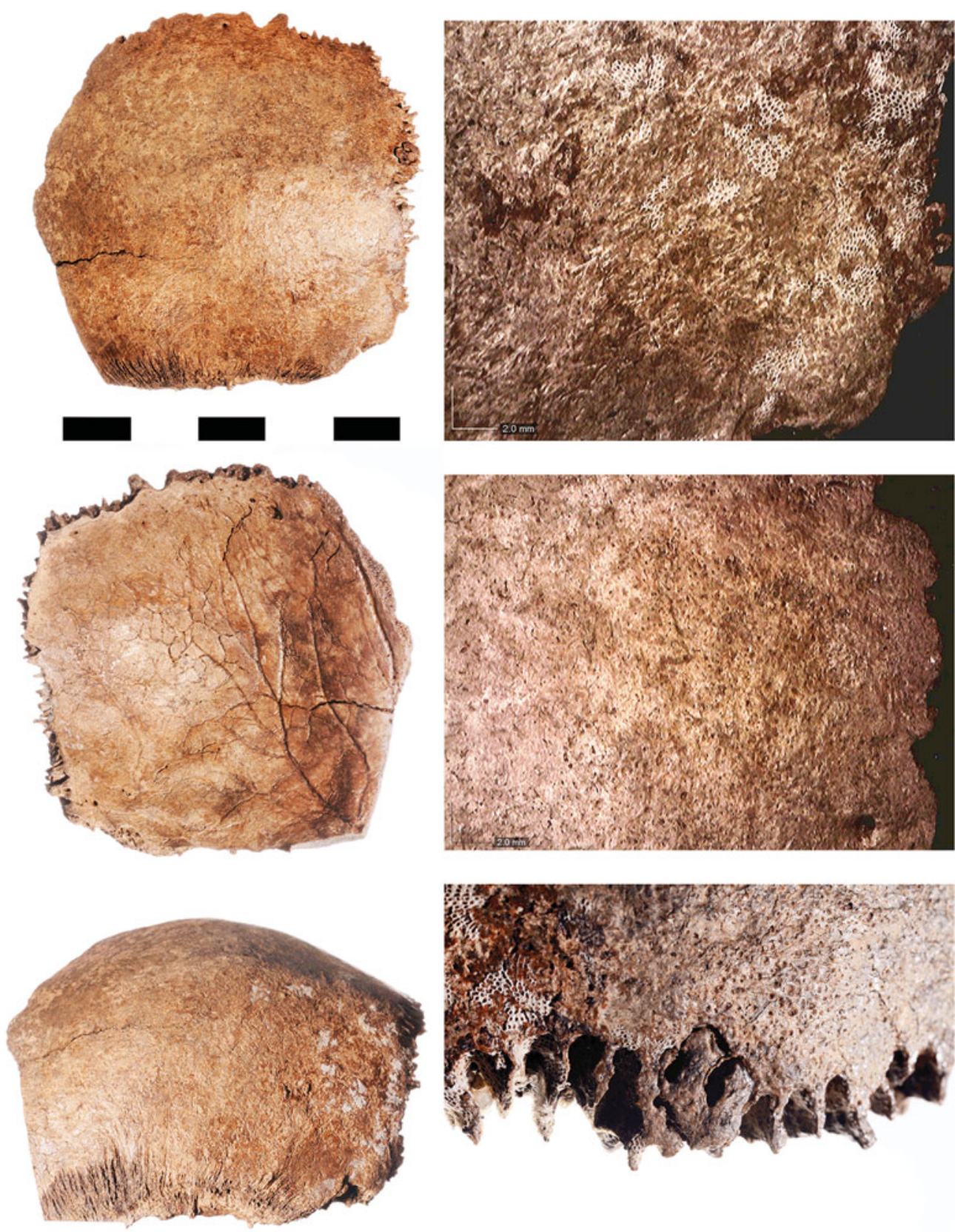

Figure 2. The human parietal bone. Left, top to bottom: outer surface; inner surface; lateral view (scale block is 50mm). Right, top to bottom (15× magnification): bryozoan colonies (white mesh-like areas); fine pitting mid-sagittal near the parietal foramen; detail of lambdoidal suture inter-digitated with pieces of occipital bone (photographs: National Museum of Antiquities/Faculty of Archaeology).

(C) Antiquity Publications Ltd, 2018 
Table 1. Radiocarbon and stable isotope data for Late Glacial remains from the North Sea (date calibration modelled in OxCal v.4.2, using IntCal13 calibration curve (Bronk Ramsey 2009; Reimer et al. 2013)).

\begin{tabular}{|c|c|c|c|c|c|c|c|c|c|c|}
\hline $\begin{array}{l}\text { Laboratory } \\
\text { number }\end{array}$ & $\begin{array}{l}\text { Site, approx. } \\
\text { coordinates }\end{array}$ & $\begin{array}{l}\text { Sample } \\
\text { material }\end{array}$ & $\begin{array}{c}{ }^{14} \mathrm{C} \text { age }(\mathrm{BP} \pm \\
1 \text {-sigma })\end{array}$ & $\begin{array}{l}\text { Calibrated age } \\
\text { (cal BP) 2-sigma }\end{array}$ & $\delta^{13} \mathrm{C}(\%)$ & $\delta^{15} \mathrm{~N}(\% \mathrm{o})$ & $\mathrm{C} \%$ & $\mathrm{~N} \%$ & $\mathrm{C}: \mathrm{N}$ ratio & Reference \\
\hline GrA-58271 & $\begin{array}{l}\text { Eurogeul, } \\
\text { N52/E4 }\end{array}$ & $\begin{array}{l}\text { Parietal bone, } \\
\text { Homo } \\
\text { sapiens }\end{array}$ & $11050 \pm 50$ & $13058-12779$ & -20.61 & 9.73 & 41.6 & 14.9 & 3.3 & This paper \\
\hline GrA-28364 & $\begin{array}{l}\text { SW of Brown } \\
\text { Bank, } \\
\text { N52/E3 }\end{array}$ & $\begin{array}{l}\text { Metatarsus, } \\
\text { Bos/Bison }\end{array}$ & $11560 \pm 50$ & $13480-13285$ & -20.62 & 3.85 & 37.9 & 14.5 & 3.1 & This paper \\
\hline GrA-34644 & $\begin{array}{l}\text { SW of Brown } \\
\text { Bank, } \\
\text { N52/E3 }\end{array}$ & $\begin{array}{l}\text { Mandibula, } \\
\text { Gulo gulo }\end{array}$ & $10730 \pm 60$ & $12735-12575$ & -21.19 & n.d. & 33.9 & - & - & Mol et al. 2008 \\
\hline OxA-1950 & $\begin{array}{l}\text { Leman and } \\
\text { Ower Bank, } \\
\text { N53/E2 }\end{array}$ & $\begin{array}{l}\text { Barbed point, } \\
\text { antler }\end{array}$ & $11740 \pm 150$ & $13945-13281$ & -21 & n.d. & n.a. & - & - & Housley 1991 \\
\hline
\end{tabular}


Luc Amkreutz et al.
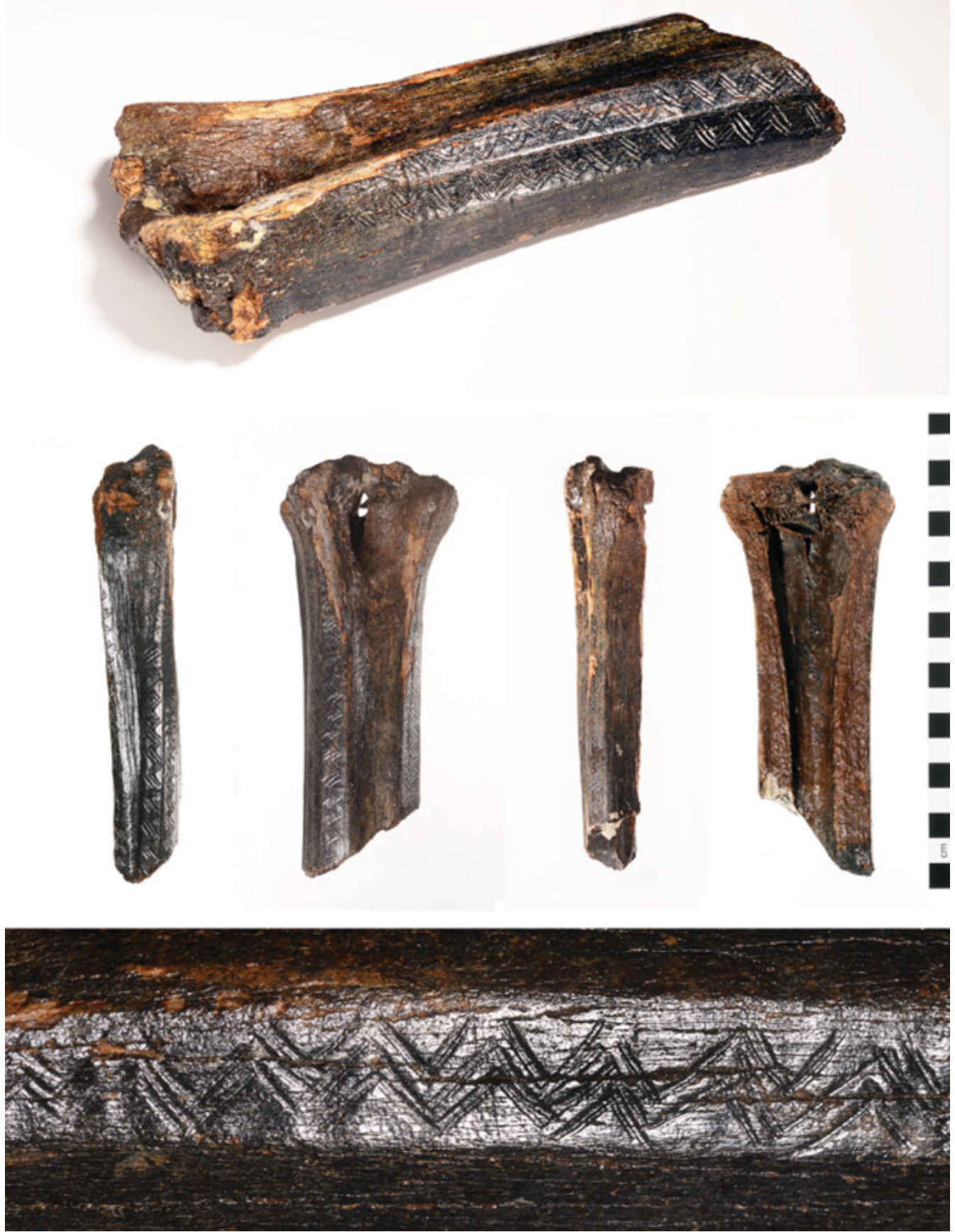

Figure 3. The decorated bovid metatarsal (photographs: National Museum of Antiquities).

(C) Antiquity Publications Ltd, 2018 
surface of the metatarsus is not decorated, but the surface is covered with shorter and longer straight to curved scratches (probably intentionally made). The pattern of decoration consists of five rows preserving 20/21, 14, 13, 12 and 7 complete or partial zigzags. The zigzags consist mostly of sequences of three parallel straight strokes, probably the result of multiple incisions with a flint implement.

Detailed analysis of one row indicates that the first few zigzags are very regular, and formed by straight, parallel, accurate strokes with similar microtraces. After the ninth series of three strokes, the cuts become more variable. The zigzags become less regular and the strokes are more variable and curved, and frequently do not overlap or connect. Despite irregularities in the incisions, great care was taken to stay within the limits of the facet. The similarity of microtraces within individual strokes suggests that this was not due to a change of incising tool, but more probably a change of gesture combined with positioning of the bone during incision.

\section{Stable isotope analysis}

The two bones were sampled for carbon $\left(\delta^{13} \mathrm{C}\right)$ and nitrogen $\left(\delta^{15} \mathrm{~N}\right)$ stable isotope analysis (Table 1). The stable isotope ratios can be used to reconstruct past diets and food webs (Layman et al. 2012). In temperate environments dominated by C3-vegetation, the $\delta^{13} \mathrm{C}$ values vary among primary producers and primarily differentiate between the terrestrial and marine source of dietary carbon (DeNiro \& Epstein 1978). The $\delta^{15} \mathrm{~N}$ values indicate the trophic level in the food web with a stepwise enrichment of 3-5\% from prey to predator (DeNiro \& Epstein 1981; Peterson \& Fry 1987). The stable isotope values of the bovid bone are within the expected range for herbivores during the Allerød (Stevens et al. 2009). The $\delta^{13} \mathrm{C}$ value of the human parietal bone is almost identical to the value of the bovid. The $\delta^{15} \mathrm{~N}$ value is $5.9 \%$ higher than that of the bovid, which is relatively high for the spacing between herbivore and human.

\section{Discussion}

Late Palaeolithic human remains and art objects are rare in Northern Europe. Skeletal remains of only twelve individuals (including the parietal from Eurogeul) are known from a time period spanning two millennia. Other human remains are known from BonnOberkassel and Neuwied-Irlich (Germany), Kendrick's Cave (Wales) and Waulsort Cave X (Belgium) (Baales 2002; Bronk Ramsey et al. 2002; Richards et al. 2005; Pettitt 2012; Holzkämper et al. 2014: 170-71). Bonn-Oberkassel, Irlich and Kendrick's Cave are dated to the early part of the Allerød, whereas Waulsort Cave X is dated to the boundary of the Allerød and the Younger Dryas. Given this small sample, it is perhaps noteworthy that two individuals (Eurogeul and Irlich) display pitting on the cranial vault. The Late Glacial skeleton of Villabruna 1 (Italy) provides a clear example of healed porotic hyperostosis, probably caused by a parasitic infection leading to anaemia (Vercellotti et al. 2010). In the Eurogeul case, the near complete healing of the lesion precludes a differential diagnosis. Nonetheless, these individuals serve as a reminder that hunter-gatherers suffered from pathological conditions, as did later agriculturalist populations.

(C) Antiquity Publications Ltd, 2018 


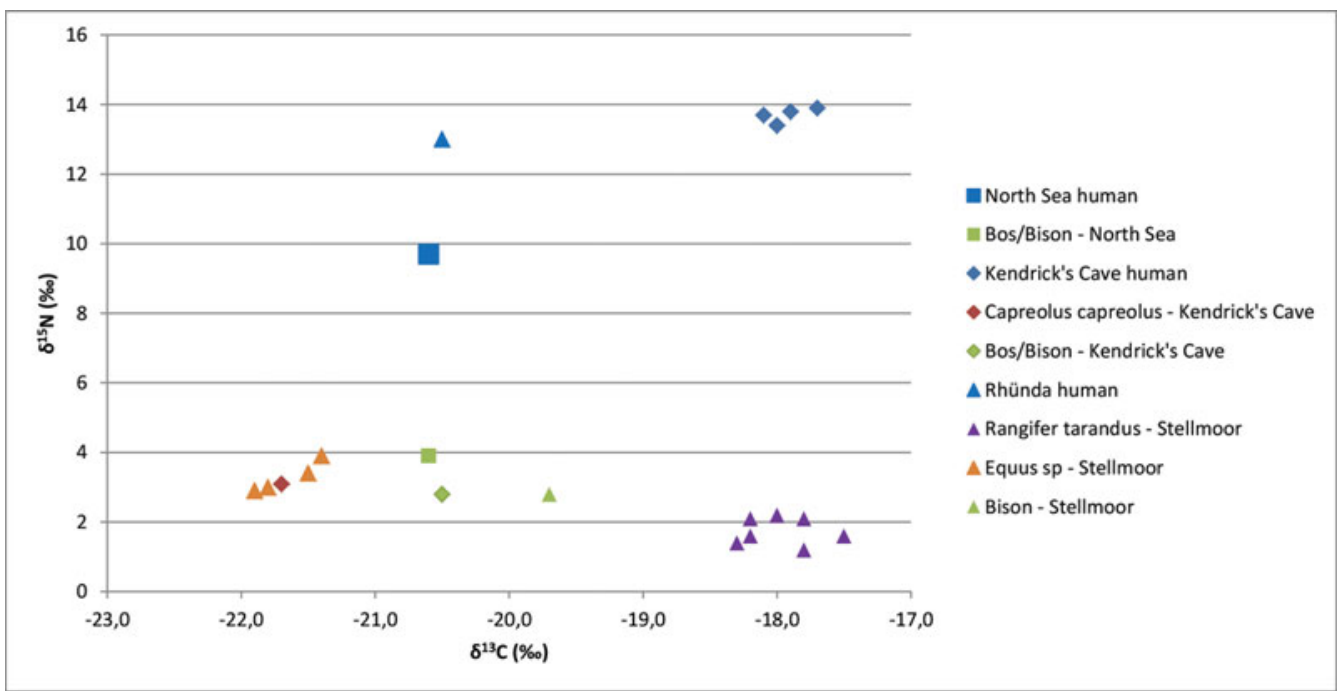

Figure 4. Stable carbon and nitrogen data for humans and herbivores from the North Sea, Kendrick's Cave and Rhünda. Data provided in OSM.

Stable isotope values for the parietal indicate a predominantly terrestrial source of dietary protein. The $\delta^{15} \mathrm{~N}$ value is, however, 5.9\%o higher than that for the bovid. This calls into question whether the slightly earlier bovid is representative of the herbivore fauna at the time of the human parietal. Another possibility is the human consumption of a small quantity of freshwater resources. Other evidence suggests an increase in the exploitation of aquatic, marine and freshwater resources in Late Glacial Northern Europe (Drucker et al. 2015). For example, stable isotope values for human remains from Kendrick's Cave indicate a major contribution of marine and freshwater resources, while the values of the Younger Dryas Rhünda specimen suggest systematic exploitation of freshwater resources (Richards et al. 2005; Stevens et al. 2010; Drucker et al. 2015) (Figure 4). In addition, Federmesser sites in the Netherlands and Germany contain archaeological evidence for freshwater resources, including pike and salmon (Baales 2002; Lauwerier \& Deeben 2011). The stable isotope values for the parietal are not, however, consistent with a large contribution of aquatic resources to the diet of this specific Late Glacial individual. That a small aquatic contribution cannot be excluded raises the problem of a possible reservoir effect on the ${ }^{14} \mathrm{C}$ date of the parietal. Reliable information on the reservoir effect of North Sea samples is currently lacking (van der Plicht et al. 2016), but could make the ${ }^{14} \mathrm{C}$ date of the parietal too old by several hundred years. Overall, the data suggest that subsistence strategies in the Late Glacial were a diverse mix of marine, freshwater and terrestrial resources depending on regional conditions. The North Sea region was probably dominated by foragers with mainly terrestrial diets.

The cultural realm of these Late Glacial foragers is not well known. Compared to that of the Late Magdalenian, Late Palaeolithic art is rare and even more enigmatic. Geometric engravings on stone, on the cortex of flint and flint tools, for example, form the most widespread category of Late Palaeolithic art in Northern Europe (e.g. Arts 1988; Baales (C) Antiquity Publications Ltd, 2018 


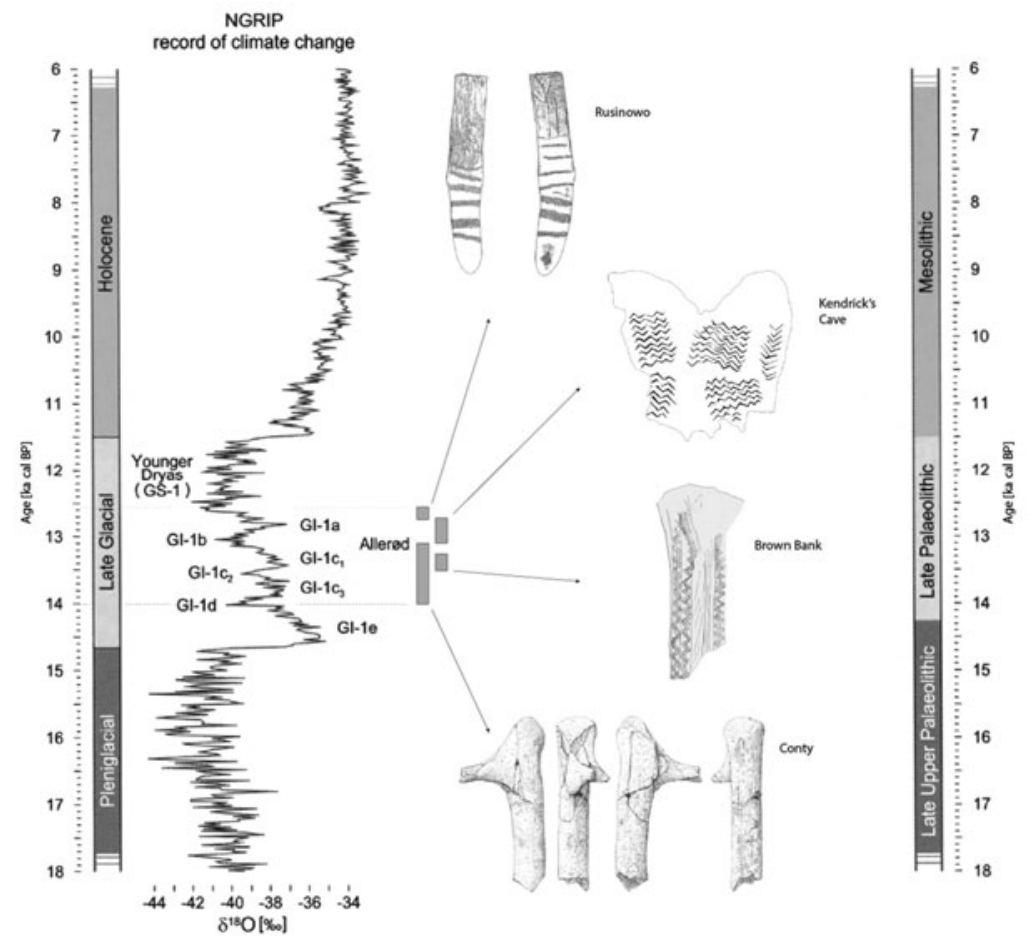

Figure 5. Overview of Late Palaeolithic geometric art in Northern Europe (approximate calibrated dates indicated; chronostratigraphy, climate record and archaeological periods follow Veil et al. 2012; artefact drawings: Rusinowo after Ptonka et al. 2011; Kendrick's Cave after Sieveking 1971; Conty after Fritz 2012).

2002). In addition, there are a few examples of figurative art: an amber elk figurine from Weitsche (Germany) and a bone contour découpé, possibly depicting the outline of a cervid, from Bonn-Oberkassel (Germany) (Veil et al. 2012). Another amber figurine from Dobiegniew (Poland), depicting a horse, is similar to the Weitsche elk, but was found out of context and is undated (Veil et al. 2012). Another surface find is a pebble retoucher engraved with two elks from Windeck (Heuschen et al. 2006). A sandstone shaft smoother from Niederbieber (area II) is incised with a series of lines interpreted as schematic female figures (Baales \& Street 1996).

To our knowledge, there are three close parallels for the decorated bone from the North Sea (Figure 5). The best known is probably the decorated horse mandible from Kendrick's Cave (Wales), recently dated to $11050 \pm 90$ BP (OxA-X-2185-26) (Sieveking 1971; Bjelkhagen \& Cook 2010). The decoration consists of four blocks of herringbone motifs and one row of ten single chevrons. The front pair of the blocks consists of seven rows of zigzags, and the rear pair has nine rows. The blocks on the left are highly regular with connecting lines, whereas the two blocks on the right contain an irregular number of strokes, several overshoots and open apexes. Another parallel was excavated from the lower level of Conty (France) and consists of a partially preserved design on deer antler (Fritz 
2012). The radiocarbon dates for the site range between 11900 and 11400 BP (Coudret \& Fagnart 1997). It is decorated with a herringbone motif with more than 34 very fine zigzag lines perpendicular to the beam. The lines are preserved on different sides of the antler. One block of five zigzags is executed vertically near the base of the antler. The third parallel is a decorated elk antler from Rusinowo (Poland) directly dated to $10700 \pm 60 \mathrm{BP}$ (Poz-14541, Płonka et al. 2011). The ornamentation consists of six herringbone motifs and one zigzag line on one side, and eight herringbone motifs and one anthropomorphic figure on the other. The individual zigzag lines display different levels of skill, suggesting that several people created the decoration.

The decorated objects from Late Palaeolithic Northern Europe are similar in terms of the techniques used and designs executed. The design and motion patterns derived from the geometric motifs share several aspects of similarly aged Azilian engraved art from Southern Europe (Couraud 1985; D’Errico 1994), such as repetitive gestures, a quest for symmetry, the repetition of motifs on several surfaces and preparation of the surface before engraving. It is consistent with a 'transcultural element' in the art of the Late Palaeolithic (d'Errico 1994). The geometric motifs are linked on the one hand to a Magdalenian tradition of geometric motifs decorating bone and antler objects, such as contours découpés, semi-circular rods, spatulae, pendants and sagaies (e.g. Leroi-Gourhan 1971; Fritz 1999). On the other hand, the medium, technique of incision, and design of chevrons and zigzags is evidence of continuity with the rich and varied geometric designs that characterise Mesolithic art of Northern Europe (e.g. Clarke 1936; Milner et al. 2016). It suggests that the symbolic shift from naturalistic figurative art to abstract geometric expression took place during the Allerød period, possibly linked to profound changes in mobility and social organisation (Naudinot et al. 2017).

\section{Conclusion}

At the end of the last Ice Age, Northern Europe was repopulated by hunter-gatherer populations from refugia in the south. The continental shelf that is now beneath the North Sea formed a large and resource-rich land mass that was exploited by colonising forager groups with a predominantly terrestrial diet, who were connected to other populations from Wales to Poland by a shared symbolic vocabulary. The two finds presented here are significant because they date to an important transitional period when substantial climatic and environmental changes co-occurred along with a major technological and sociocultural transformation affecting hunter-gatherer societies. The terrestrial diet of the Late Palaeolithic foragers, inferred from the isotopic values of the human parietal bone, forms the baseline for a gradual increase in aquatic foods seen subsequently during the Mesolithic in the region (van der Plicht et al. 2016). The geometric design of the decorated bovid bone is further evidence of a shift in symbolic expression from naturalistic figuration to geometric abstraction (Naudinot et al. 2017). As organic remains documenting this transformation are rarely preserved, the North Sea proves to be an important source for organic material culture, such as art objects and human and faunal remains. The two finds help to fill an important gap in our knowledge of the submerged biocultural heritage of the North Sea.

(C) Antiquity Publications Ltd, 2018 


\section{Acknowledgements}

The authors would like to thank the Department of Radiology of the Academic Medical Centre (AMC), Amsterdam, for granting access to perform the CT scan; J. Hagoort from the Department of Anatomy, Embryology and Physiology of the AMC for creating the 3D reconstructions of the element; I. Joosten (National Heritage Agency, Amsterdam) for access and support with use of the Hirox microscope; E. Mulder (Faculty of Archaeology, Leiden) for access and use of the Nikon stereomicroscope; J. van der Deijl (Faculty of Archaeology, Leiden) for help with the initial description of the parietal bone; W. Prummel (Zwolle) and A. Ramcharan (Faculty of Archaeology, Leiden) for assistance with the initial description and determination of the decorated bone; J. Porck for Figures 1 and 4; A. Hoekman and K. Post (North Sea Fossils, Urk) for the donation of the parietal bone to the National Museum of Antiquities (Leiden); and finally, thanks to the reviewers for the helpful, critical and constructive comments.

\section{Supplementary material}

To view supplementary material for this article, please visit https://doi.org/10.15184/aqy. 2017.195

\section{References}

Aaris-Sørensen, K. 2009. Diversity and dynamics of the mammalian fauna in Denmark throughout the Last Glacial-Interglacial cycle, 115-0 kyr BP (Fossils and Strata 57). Chichester: Wiley-Blackwell.

Arts, N. 1988. A survey of final Palaeolithic archaeology in the southern Netherlands, in M. Otte (ed.) De la Loire à l'Oder. Les civilisations du Paléolithique Final dans le nord-ouest Européen (British Archaeological Reports international series 444): 287-356. Oxford: British Archaeological Reports.

BAALes, M. 2002. Der spätpaläolithische Fundplatz Kettig: Untersuchungen zur Siedlungsarchäologie der Federmesser-gruppen am Mittelrhein (RGZM Monographie 51). Mainz: Römisch-Germanisches Zentralmuseum.

BaAles, M. \& M. Street. 1996. Hunter-gatherer behavior in a changing Late Glacial landscape: Allerød archaeology in the central Rhineland, Germany. Journal of Anthropological Research 52-53: 281-316. https://doi.org/10.1086/jar.52.3.3630086

BaAles, M., O. Jöris, M. Street, F. Bittmann, B. Weninger \& J. Wiethold. 2002. Impact of the Late Glacial eruption of the Laacher See volcano, central Rhineland, Germany. Quaternary Research 58: 273-88.

https://doi.org/10.1006/qres.2002.2379

Behrensmeyer, A.K. 1978. Taphonomic and ecologic information from bone weathering. Paleobiology 4 : 150-62. https://doi.org/10.1017/S0094837300005820

Benjamin, J., C. Bonsall, C. Pickard \& A. Fischer (ed.). 2011. Submerged prehistory. Oxford: Oxbow.
Bickett, A. \& L. Tizzard. 2015. A review of the submerged prehistory and palaeolandscapes of the British Isles. Proceedings of the Geologists'Association 126: 643-63. https://doi.org/10.1016/j.pgeola.2015.08.009

Bjelkhagen, H. \& J. Cook. 2010. Colour holography of the oldest known work of art from Wales. The British Museum Technical Research Bulletin 4: 87-94.

Björck, S. 1995. Late Weichselian to Early Holocene development of the Baltic Sea-with implications for the coastal settlements in the southern Baltic region, in A. Fischer (ed.) Man and sea in the Mesolithic. Coastal settlement above and below present sea level. Proceedings of the International Symposium Kalundborg, Denmark 1993: 23-34. Oxford: Oxbow.

Boulton, G.S., P. Dongelmans, M. Punkari \& M. Broadgate. 2001. Palaeoglaciology of an ice sheet through a glacial cycle: the European ice sheet through the Weichselian. Quaternary Science Reviews 20: 591-625. https://doi.org/10.1016/S0277-3791(00)00160-8

Bronk Ramsey, C. 2009. Bayesian analysis of radiocarbon dates. Radiocarbon 51: 337-60. https://doi.org/10.1017/S0033822200033865

Bronk-Ramsey, C.B., T.F.G. Higham, D.C. Owen, A.W.G. Pike \& R.E.M. Hedges. 2002.

Radiocarbon dates from the Oxford AMS system: archaeometry datelist 31. Archaeometry 4: 1-149. https://doi.org/10.1111/j.14754754.2002.tb01101.x

Buikstra, J.E. \& D.H. Ubelaker (ed.). 1994. Standards for data collection from human skeletal remains: seminar at the Field Museum of Natural History. Fayetteville: Arkansas Archaeological Survey. 
Bynoe, R., J.K. Dix \& F. Sturt. 2016. Of mammoths and other monsters: historic approaches to the submerged Palaeolithic. Antiquity 90: 857-75. https://doi.org/10.15184/aqy.2016.129

Chang, C., Y. Kaifu, M. Takai, R.T. Kono, R. Grün, S. Matsu'ura, L. Kinsley \& L.-K. Lin. 2014. The first archaic Homo from Taiwan. Nature Communications 6. https://doi.org/10.1038/ncomms7037.

Clark, C.D., D.J.A. Evans, A. Khatwa, T. Bradwell, C.J. Jordan, S.H. Marsh, W.A. Mitchell \& M.D. Bateman. 2004. Map and GIS database of glacial landforms and features related to the last British ice sheet. Boreas 33: 359-75. https://doi.org/10.1080/03009480410001983

Clarke, J.G.D. 1936. The Mesolithic settlement of Northern Europe. Cambridge: Cambridge University Press.

Coudret, P. \& J.-P. Fagnart. 1997. Les industries à Federmesser dans le bassin de la Somme: chronologie et identité des groupes culturels. Bulletin de la Société préhistorique française 94: 349-59.

Couraud, C. 1985. L'art azilien: origine-survivance. Paris: CNRS.

DeNiro, M.J. \& S. Epstein. 1978. Influence of diet on the distribution of carbon isotopes in animals. Geochimica et Cosmochimica Acta 42: 495-506. https://doi.org/10.1016/0016-7037(78)90199-0

- 1981. Influence of diet on the distribution of nitrogen isotopes in animals. Geochimica et Cosmochimica Acta 45: 341-51. https://doi.org/10.1016/0016-7037(81)90244-1

D'Errico, F. 1994. L'art gravé azilien. Paris: CNRS.

Drucker, D.G., W. Rosendahl, W. van Neer, M.-J. Weber, I. Görner \& H. Bocherens. 2015. Environment and subsistence in north-western Europe during the Younger Dryas: an isotopic study of the human of Rhünda (Germany). Journal of Archaeological Science: Reports 6: 690-99. https://doi.org/10.1016/j.jasrep.2015.08.002

Evans, A.M., J.C. Flatman \& N.C. Flemming (ed.). 2013. Prehistoric archaeology on the continental shelf: a global review. New York: Springer.

Flemming, N.C., M.N. ÇAĞatay, F.L. Chiocci, N. Galanidou, H. Jöns, G. Lericolais, T. Missiaen, T. Moore, A. Rosentau, D. Sakellariou, B. Skar, A. Stevenson \& H. WeERTs. 2014. Land beneath the waves: submerged landscapes and sea level change. A joint geoscience-humanities strategy for European continental shelf prehistoric research (Position Paper 21 of the European Marine Board). Ostend: European Marine Board.
FrITZ, C. 1999. Towards the reconstruction of Magdalenian artistic techniques: the contribution of microscopic analysis of mobiliary art. Cambridge Archaeological Journal 9: 189-208. https://doi.org/10.1017/S0959774300015377

- 2012. Le bois de cerf gravé et les cortex incisés de Conty. Quaternaire (Hors-série) 5: 91-94.

GeE, H. 1993. The distinction between postcranial bones of Bos primigenius Bojanus, 1827 and Bison priscus Bojanus, 1827 from the British Pleistocene and the taxonomic status of Bos and Bison. Journal of Quaternary Science 8: 79-92. https://doi.org/10.1002/jqs.3390080107

Grimm, S.B. 2016. Maps of late glacial NW-Europe. NW-EU 10W-25E 45-60N-70m GI 1c-a. Available at: http://monrepos-rgzm.de/tl_files/ monrepos/content/projektarchiv/downloads/NWEu\%2010W-25E\%2045-60N\%20-70m\% 20RGB\%20GI-1c-a\%20map\%202\%20water.jpg (accessed 4 September 2017).

Heuschen, W., F. Gelhausen, S.B. Grimm \& M. Street. 2006. Ein verzierter Retuscheur aus dem mittleren Siegtal (Nordrhein-Westfalen). Archäologisches Korrespondenzblatt 36(1): 17-28.

Hijma, M.P., K.M. Cohen, W. Roebroeks, W.E. Westerhoff \& F.S. Busschers. 2012. Pleistocene Rhine-Thames landscapes: geological background for hominin occupation of the southern North Sea region. Journal of Quaternary Science 27: 17-39. https://doi.org/10.1002/jqs.1549

Hoek, W. 1997. Late Glacial and Early Holocene climatic events and chronology of vegetation development in the Netherlands. Vegetation History and Archaeobotany 6: 197-213. https://doi.org/10.1007/BF01370442

-2000 . Abiotic landscape and vegetation patterns in the Netherlands during the Weichselian Late Glacial. Netherlands Journal of Geosciences 79: 497-509. https://doi.org/10.1017/S0016774600021983

- 2008. The Last Glacial-Interglacial transition. Episodes 31: 226-29.

(C) Antiquity Publications Ltd, 2018 
Holzkämper, J., I. Kretschmer, A. Maier, M. BaAles, A. von Berg, J.A.A. Bos, M. Bradtmöller, K. Edinborough, S. Flohr, L. Giemsch, S.B. Grimm, J. Hilpert, A.J. Kalis, T. Kerig, M.C. Langley, D. Leesch, J. Meurers-Balke, L. Mevel, J. Orschiedt, M. Otte, A. Pastoors, P. Pettitt, E. Rensink, J. Richter, F. Riede, I. Schmidt, R.W. Schmitz, S. Shennan, M. Street, Y. Tafelmaier, M.-J. Weber, K.P. Wendt, G.-C. Weniger \& A. Zimmermann. 2014. The Upper-Late Palaeolithic transition in western Central Europe. Typology, technology, environment and demography. Report on the workshop held in Rösrath, 21 $1^{\text {st }}-24^{\text {th }}$ June 2012. Archäologische Informationen 36: 161-86.

Housley, R.A. 1991. The Late Glacial in north-west Europe: human adaptation and environmental change at the end of the Pleistocene, in R.N.E. Barton, A.J. Roberts \& D.A. Roe (ed.) Late Glacial in NW Europe: 25-39. London: Council for British Archaeology.

Housley, R.A., C.S. Gamble, M. Street \& P. Pettitt. 1997. Radiocarbon evidence for the Late Glacial human recolonisation of Northern Europe. Proceedings of the Prehistoric Society 63: 25-54. https://doi.org/10.1017/S0079497X0000236X

Hublin, J.J., D. Weston, Ph. Gunz, M. Richards, W. Roebroeks, J. Glimmerveen \& L. Anthonis. 2009. Out of the North Sea: the Zeeland Ridges Neandertal. Journal of Human Evolution 57: 777-85. https://doi.org/10.1016/j.jhevol.2009.09.001

Ivy-Ochs, S., H. Kerschner, P.W. KubiK \& C. SchlÜChter. 2006. Glacier response in the European Alps to Heinrich event 1 cooling: the Gschnitz stadial. Journal of Quaternary Science 21: 115-30. https://doi.org/10.1002/jqs.955

Lambeck, K., Y. Yokoyama \& T. Purcell. 2002. Into and out of the Last Glacial Maximum: sea level change during oxygen isotope stages 3 and 2 . Quaternary Science Reviews 21(1-3): 343-60. https://doi.org/10.1016/S0277-3791(01)00071-3

Lambeck, K., H. Rouby, A. Purcell, Y. Sun \& M. Sambridge. 2014. Sea level and global ice volumes from the Last Glacial Maximum to the Holocene. Proceedings of the National Academy of Sciences of the USA 111: 15296-303. https://doi.org/10.1073/pnas.1411762111

Lauwerier, R.C.G.M. \& J. Deeben. 2011. Burnt animal remains from Federmesser sites in the Netherlands. Archäologisches Korrespondenzblatt 41: $1-20$.
Layman, C.A., M.S. Araujo, R. Boucek, C.M. Hammerschlag-Peyer, E. Harrison, Z.R. Jud, P. Matich, A.E. Rosenblatt, J.J. Vaudo, L.A. Yeager, D.M. Post \& S. Bearhor. 2012. Applying stable isotopes to examine food-web structure: an overview of analytical tools. Biological Reviews 87: 545-62. https://doi.org/10.1111/j.1469185X.2011.00208.x

Leroi-Gourhan, A. 1971. Préhistoire de l'art occidentale. Paris: Mazenod.

Louwe Koorjmans, L.P. 1970. Mesolithic bone and antler implements from the North Sea and the Netherlands. Berichten van de Rijksdienst voor Oudheidkundig Bodemonderzoek 20-21: 27-73.

Lundqvist, J. \& B. Wohlfarth. 2001. Timing and east-west correlation of south Swedish ice marginal lines during the Late Weichselian. Quaternary Science Reviews 20: 1127-48. https://doi.org/10.1016/S0277-3791(00)00142-6

McIlvaine, B.K. 2013. Implications of reappraising the iron-deficiency anemia hypothesis. International Journal of Osteoarchaeology 25: 997-1000. https://doi.org/10.1002/oa.2383

Milner, N., M. Bamforth, G. Beale, J.C. Carty, K. Chatzipanagis, S. Croft, C. Conneller, B. Elliott, L.C. Fitton, B. Knight, R. Kröger, A. Little, A. Needham, H.K. Robson, C.C.A. Rowley \& B. TAYlor. 2016. A unique engraved shale pendant from the site of Star Carr: the oldest Mesolithic art in Britain. Internet Archaeology 40. https://doi.org/10.11141/ia.40.8.

Mol, D., K. Post, J.W.F. Reumer, J. van der Plicht, J. de Vos, B. van Geel, G. van Reenen, J.-P. Pals \& J. Glimmerveen. 2006. The Eurogeul-first report of the palaeontological, palynological and archaeological investigations of this part of the North Sea. Quaternary International 142-43: 178-85. https://doi.org/10.1016/j.quaint.2005.03.015

Mol, D., J. de Vos, R. Bakker, B. van Geel, J. Glimmerveen, J. van der Plicht \& K. Post. 2008. Kleine encyclopedie van het leven in het Pleistoceen: mammoeten, neushoorns en andere dieren van de Noordzeebodem. Diemen: Veen.

Naudinot, N., C. Bourdier, M. Laforge, C. Paris, L. Bellot-Gurlet, S. Beyries, I. Théry-Parisot \& M. Le Goffic. 2017. Divergence in the evolution of Paleolithic symbolic and technological systems: the shining bull and engraved tablets of Rocher de l'Impératrice. PLoS ONE 12: e0173037. https://doi.org/10.1371/journal.pone.0173037.

ORTNER, D.J. 2003. Identification of pathological conditions in human skeletal remains. San Diego (CA): Elsevier. 
Parfitt, S.A., R.W. Barendregt, M. Breda, I. Candy, M.J. Collins, G.R. Coope, P. Durbidge, M.H. Field, J.R. Lee, A.M. Lister, R. Mutch, K.E.H. Penkman, R.C. Preece, J. Rose, C.B. Stringer, R. Symmons, J.E. Whittaker, J.J. Wymer \& A.J. Stuart. 2005. The earliest record of human activity in Northern Europe. Nature 438: 1008-1012. https://doi.org/10.1038/nature04227

Parfitt, S.A., N. Ashton, S.G. Lewis, R.L. Abel, G.R. Coope, M.H. Field, R. Gale, P.G. Hoare, N.R. Larkin, M.D. Lewis, V. Karloukovski, B.A. Maher, S.M. Peglar, R.C. Preece, J.E. Whittaker \& C.B. Stringer. 2010. Early Pleistocene human occupation at the edge of the boreal zone in northwest Europe. Nature 466: 229-33. https://doi.org/10.1038/nature09117

Peeters, J.H.M. \& K.M. Cohen. 2014. Introduction to North Sea submerged landscapes and prehistory. Netherlands Journal of Geosciences 93: 3-5. https://doi.org/10.1017/njg.2014.5

Peeters, J.H.M. \& G. Momber. 2014. The southern North Sea and the human occupation of northwestern Europe after the Last Glacial Maximum. Netherlands Journal of Geosciences 93(1-2): 55-70. https://doi.org/10.1017/njg.2014.3

Peeters, J.H.M., N. Flemming \& P. Murphy. 2009. North Sea prehistory research and management framework (NSPRMF) 2009. Amersfoort: Rijksdienst voor het Cultureel Erfgoed/English Heritage.

Peterson, B.J. \& B. Fry. 1987. Stable isotopes in ecosystem studies. Annual Review of Ecology and Systematics 18: 295-320. https://doi.org/ 10.1146/annurev.es.18.110187.001453

Petтitт, P. 2012. The Palaeolithic origins of human burial. London: Routledge.

PŁonka, T., K. Kowalski, M. Malkiewicz, J. Kuryszko, P. Socha \& K. Stefaniak. 2011. A new ornamented artefact from Poland: final Palaeolithic symbolism from an environmental perspective. Journal of Archaeological Science 38: 723-33. https://doi.org/10.1016/j.jas.2010.10.026

Posth, C., G. Renaud, A. Mittnik, D.G. Drucker, H. Rougier, C. Cupillard, F. Valentin, C. Thevenet, A. Furtwängler, C. Wißing, M. Francken, M. Malina, M. Bolus, M. Lari, E. Gigli, G. Capecchi, I. Crevecoeur, C. Beauval, D. Flas, M. Germonpré, J. van der Plicht, R. Cottiaux, B. Gély, A. Ronchitelli, K. Wehrberger, D. Grigorescu, J. Svoboda, P. Semal, D. Caramelli, H. Bocherens, K. Harvati, N.J. Conard, W. HaAK, A. Powell \& J. Krause. 2017. Pleistocene mitochondrial genomes suggest a single major dispersal of non-Africans and a Late Glacial population turnover in Europe. Current Biology 26: 827-33.

(C) Antiquity Publications Ltd, 2018
Reimer, P.J., E. Bard, A. Bayliss, J.W. Beck, P.G. Blackwell, C. Bronk Ramsey, C.E. Buck, H. Cheng, R.L. Edwards, M. Friedrich, P.M. Grootes, T.P. Guilderson, H. Haflidason, I. Hajdas, C. Hatté, T.J. Heaton, D.L. Hoffmann, A.G. Hogg, K.A. Hughen, K.F. Kaiser, B. Kromer, S.W. Manning, M. Niu, R.W. Reimer, D.A. Richards, E.M. ScotT, J.R. Southon, R.A. Staff, C.S.M. Turney \& J. van der Plicht. 2013. IntCal13 and Marine13 radiocarbon age calibration curves $0-50,000$ years cal BP. Radiocarbon 55: 1869-87. https://doi.org/10.2458/azu_js_rc.55.16947.

Richards, M.P., R. Jacobi, J. Cook, P.B. Рettitt \& C.B. Stringer. 2005. Isotope evidence for the intensive use of marine foods by Late Upper Palaeolithic humans. Journal of Human Evolution 49: 390-94. https://doi.org/10.1016/j.jhevol.2005.05.002

Sieveking, G. DE G. 1971. The Kendrick's Cave mandible. The British Museum Quarterly 35(1-4): 230-50. https://doi.org/10.2307/4423084

Stevens, R.E., T.C. O’Connell, R.E.M. Hedges \& M. StreEt. 2009. Radiocarbon and stable isotope investigations at the central Rhineland sites of Gönnersdorf and Andernach-Martinsberg, Germany. Journal of Human Evolution 57: 131-48. https://doi.org/10.1016/j.jhevol.2009.01.011

Stevens, R.E., R.M. Jaсовi \& T.F.G. Нigham. 2010. Reassessing the diet of Upper Palaeolithic humans from Gough's Cave and Sun Hole, Cheddar Gorge, Somerset, UK. Journal of Archaeological Science 37: 52-61. https://doi.org/10.1016/j.jas.2009.08.019

Stuart-Macadam, P.L. 1992. Porotic hyperostosis: a new perspective. American Journal of Physical Anthropology 87: 39-47. https://doi.org/10.1002/ajpa.1330870105

Tizzard, L., A.R. Bicket, J. Benjamin \& D. De LoecKer. 2014. A Middle Palaeolithic site in the southern North Sea: investigating the archaeology and palaeogeography of Area 240. Journal of Quaternary Science 29: 698-710. https://doi.org/10.1002/jqs.2743

van der Plicht, J., L.W.S.W. Amkreutz, M.J.L.Th. Niekus, J.H.M. Peeters \& B.I. Smit. 2016. Surf ' $n$ ' turf in Doggerland: dating, stable isotopes and diet of Mesolithic human remains from the southern North Sea. Journal of Archaeological Science: Reports 10: 110-18. https://doi.org/10.1016/j.jasrep.2016.09.008 
van Kolfschoten, T. \& C. Laban. 1995. Pleistocene terrestrial mammal faunas from the North Sea. Mededelingen Rijks Geologische Dienst 52: 135-51.

Veil, St., K. Breest, P.M. Grootes, M. Nadeau \& M. HüLs. 2012. A 14,000-year-old amber elk and the origins of northern European art. Antiquity 86: 660-73.

https://doi.org/10.1017/S0003598X00047839

Vercellotti, G., D. Caramella, V. Formicola, G. Fornaciari \& C.S. Larsen. 2010. Porotic hyperostosis in a Late Upper Palaeolithic skeleton (Villabruna 1, Italy). International Journal of Osteoarchaeology 20: 358-36.
Weaver, A.J., O.A. Saenko, P.U. Clark \& J.X. Mitrovica. 2003. Meltwater pulse 1A from Antarctica as a trigger of the Bølling-Allerød warm interval. Science 299: 1709-13. https://doi.org/10.1126/science. 1081002

Wygal, B.T. \& S.M. Heidenreich. 2014. Deglaciation and human colonization of Northern Europe. Journal of World Prehistory 27: 111-44. https://doi.org/10.1007/s10963-014-9075-z

Received: 30 November 2016; Accepted: 1 March 2017; Revised: 28 April 2017 